\title{
PENGARUH PEMBERIAN KOMPOS DAN UREA TERHADAP PRODUKSI Indigofera zollingeriana
}

\section{EFFECT OF COMPOST AND UREA ON PRODUCTION OF Indigofera zollingeriana}

\author{
Lia Rumlus ${ }^{1)}$, Onesimus Yoku ${ }^{2)}$ dan Budi Santoso ${ }^{2)}$ \\ ${ }^{1)}$ Program Studi S2 Ilmu Peternakan, Program Pascasarjana Universitas Papua \\ ${ }^{2)}$ Fakultas Peternakan Universitas Papua \\ *Email: b.santoso@unipa.ac.id
}

\begin{abstract}
ABSTRAK
Produktivitas ternak potong yang rendah disebabkan oleh status nutrisi dan suplai hijauan sepanjang tahun yang rendah terutama pada musim kemarau. Indigofera zollingeriana merupakan salah satu tanaman pakan jenis leguminosa yang memiliki kandungan nutrien dan produksi yang tinggi, berumur panjang, dapat beradaptasi pada semua jenis tanah, dan toleran terhadap kekeringan. Penelitian ini bertujuan untuk mengetahui pengaruh pemberian pupuk kompos dan pupuk urea terhadap produksi tanaman I. zollingeriana. Penelitian disusun dalam rancangan acak lengkap pola faktorial. Faktor pertama adalah perlakukan pupuk kompos (K) dengan 3 taraf, yaitu K0 (tanpa pupuk kompos sebagai kontrol), K1 (5 ton/ha pupuk kompos) dan K2 (10 ton/ha pupuk kompos). Faktor kedua adalah pupuk urea dengan 4 taraf, masing-masing N0 (tanpa urea), N1 (150 kg/ha urea), N2 (300 kg/ha urea), $\mathrm{N} 3$ (450 kg/ha urea). Terdapat 48 satuan percobaan. Variabel yang diamati meliputi produksi hijauan segar, produksi bahan kering, rasio daun batang dan kandungan nutrien. Hasil penelitian menunjukkan bahwa kombinasi perlakuan pupuk kompos dan urea berpengaruh nyata terhadap produksi tanaman I. zollingeriana, yaitu terhadap produksi bahan kering. Produksi bahan kering tertinggi yaitu sebesar 38,57 $\mathrm{g} /$ polybag diperoleh pada kombinasi perlakuan 10 ton kompos/ha dengan $300 \mathrm{~kg}$ urea/ha (K2N2).
\end{abstract}

Kata Kunci: pupuk, kompos, urea, Indigofera zolligeriana, produksi

\begin{abstract}
The low productivity of beef cattle is due to the low nutritional status and supply of forage throughout the year, especially during the dry season. Indigofera zollingeriana is one of the leguminous forage plants that has high nutrient content and production, has a long life, can adapt to all types of soil, and is drought tolerant. The study aimed to determine the effect of compost and urea fertilizer on the production of I. zollingeriana. The research was arranged in a factorial completely randomized design. The first factor was the treatment of compost $(\mathrm{K})$ with 3 levels, each $\mathrm{K} 0$ (without compost as control), K1 (5 tons/ha compost) and K2 (10 tons/ha compost). The second factor was urea fertilizer with 4 levels, which are N0 (without urea), N1 (150 kg/ha urea), N2 (300 kg/ha urea), N3 (450 kg/ha urea). There were 48 experimental units. The variables observed were fresh forage production, dry matter production, stem leaf ratio and nutrient content. Research result showed that the
\end{abstract}


interaction between compost and urea had a significant effect on the production of $I$. zollingeriana plants, which was the dry matter The highest dry matter production $38.57 \mathrm{~g} /$ polybag reached by the interaction between 10 tons of compost/ha with 300 $\mathrm{kg}$ of urea/ha (K2N2).

Keywords: fertilizer, compost, urea, $i$. zollingeriana, production

\section{PENDAHULUAN}

Ternak ruminansia di Indonesia memiliki peranan yang sangat penting dalam memenuhi kebutuhan daging nasional. Kebutuhan ini sebagian besar merupakan kontribusi dari peternakan rakyat dan kekurangannya dipasok impor. Rendahnya produktivitas ternak potong disebabkan karena status nutrisi dan suplai hijauan sepanjang tahun yang rendah terutama pada musim kemarau. Hal ini karena petani hanya mengandalkan hijauan pakan lokal yang terdapat di sekitar pekarangan, perkebunan, hutan dan ladang tanpa memanfaatkan lahan yang tersedia untuk memanfaatkan penanaman pakan hijauan berkualitas (Herdiawan, 2014).

Pemberian pakan hijauan berupa rumput saja tidak mampu memberikan kualitas yang baik bagi produksi ternak. Koten, et al. (2014), menyatakan bahwa pakan hijauan yang merupakan kombinasi rumput dan leguminosa dibutuhkan untuk melengkapi nutrisi yang diperlukan ternak. Berbagai tanaman leguminosa berpotensi menyediakan pakan hijauan karena kualitas nutrisi yang lebih baik dibandingkan rumput dan daya adaptasi yang tinggi terhadap kekeringan (Khamseekhiew, et al., 2001).

Salah satu jenis leguminosa pohon yang baik dengan adaptasi tinggi adalah Indigofera zollingeriana. Lemmens dan Cardon (2005) dalam Jaya et al. (2016) menyatakan bahwa $I$. zollingeriana merupakan salah satu tanaman pakan jenis leguminosa yang memiliki kandungan nutrien dan produksi yang tinggi, berumur panjang dan dapat beradaptasi pada semua jenis tanah, serta toleran terhadap kekeringan. Menurut Sirait, et al. (2009) I. zollingeriana memiliki pertumbuhan yang cepat dengan tinggi rata-rata $418 \mathrm{~cm}$ pada umur 7 bulan. Produktivitas Indigofera $s p$. 
mencapai 30 ton/ha/tahun bahan kering (Tarigan, et al. 2010). Tanaman ini memiliki kandungan bahan kering 21,97\%, abu 6,41\%, protein kasar (PK) 24,17\%, neutral detergent fiber (NDF) 54,24\%, acid detergent fiber (ADF) 44,69\% dan energi kasar 4.039 $\mathrm{Kka} / \mathrm{kg}$ (Balitbang Pertanian, 2014).

Pertumbuhan dan nilai nutrisi hijauan pakan ternak sangat ditentukan oleh kesuburan tanah. Kondisi tanah di wilayah Wilayah Distrik Masni Kabupaten Manokwari dilaporkan pada kondisi kesuburan yang rendah (Dinas Tanaman Pangan dan Hortikultura, 2016). Rendahnya kesuburan tanah dalam tanah sangat mempengaruhi pertumbuhan dan produksi tanaman hijauan pakan ternak, oleh sebab itu perlu dilakukan penambahan unsur hara ke dalam tanah. Hartatik, et al. (2015) menyatakan bahwa untuk mengurangi kemunduran kesuburan tanah dan meningkatkan produksi hasil tanaman yang berkelanjutan perlu pemanfaatan pupuk organik. Sistem pertanian bisa menjadi berkelanjutan jika kandungan bahan organik tanah lebih dari $2 \%$ (Handayanto, 1999). Menurut Ali, et al. (2014), penggunaan pupuk standar untuk tanaman I. zollingerina dan Leucaena leucocephala, masingmasing untuk bahan organik (kotoran sapi) sebanyak 10 ton/ha dan penggunaan pupuk anorganik (NPK) sebesar $50 \mathrm{~kg} / \mathrm{ha} /$ tahun berpengaruh terhadap produksi dan nilai nutrisi $I$. Zollingeriana lebih tinggi dari $L$. leucocephala.

Tanaman I. zollingeriana saat ini mulai dikembangkan sebagai hijauan pakan ternak unggul jenis leguminosa pohon mulai dikembangkan di wilayah Distrik Masni tahun 2016 oleh Balai Perbibitan Ternak Hijauan Makanan Ternak (BPT-HMT) Papua Barat. Namun pengembangannya belum optimal, sehingga masih dibutuhkan kajian terkait adaptasi tanaman terhadap lingkungan, peningkatan produktivitas tanaman dan kesesuaian tanah serta respon pertumbuhan tanaman terhadap pemupukan.

Ketersediaan pakan secara kontinyu, dengan kuantitas dan kualitas yang baik, dinilai masih menjadi penghambat pengembangan usaha sapi potong dan kambing di wilayah Distrik Masni. Introduksi jenis 
hijauan pakan unggul menjadi salah satu solusi, namun perlu adanya adaptasi terhadap iklim mikro dan tanah sebagai media tumbuh. Penelitian Yafur (2017) menunjukkan bahwa kondisi tanah di wilayah Distrik Masni memiliki kandungan C-organik yang rendah sebesar $1,50 \%$, N-total $0,24 \%$ termasuk kriteria sedang, nilai $\mathrm{pH} \mathrm{H}_{2} \mathrm{O} 5,9$ dengan kategori agak masam, dan kandungan $\mathrm{P}_{2} \mathrm{O}_{5} \quad 66$ $\mathrm{mg} / 100 \mathrm{~g}$ pada kriteria tinggi dan nilai $\mathrm{K}_{2} \mathrm{O} 776 \mathrm{mg} / 100 \mathrm{~g}$ termasuk kategori tinggi. Data tersebut menunjukkan bahwa kondisi tanah tidak subur dengan kandungan bahan organik tanah pada batas minimal, sehingga perlu dilakukan penyediaan bahan organik dan unsur hara terutama Nitrogen (N). Menurut Stevenson (1982) walaupun peran bahan organik terhadap suplai hara bagi tanaman kurang, namun bahan organik berperan paling besar dan penting dengan kesuburan fisik tanah. Jika kandungan humus tanah kandungan semakin berkurang, maka lambat laun tanah akan menjadi keras, kompak dan bergumpal, sehingga menjadi kurang produktif.
Informasi level pemberian dosis kompos dan urea yang optimal pada $I$. zollingeriana masih terbatas. Selanjutnya, tujuan penelitian ini adalah untuk mengetahui pengaruh pemberian kompos dan urea terhadap produksi segar, bahan kering, rasio batang dan dauan dan komposisi kimia I. zollingeriana.

\section{METODE}

\section{Waktu dan Tempat}

Penelitian berlangsung bulan Mei-Oktober 2018 di Balai Perbibitan Ternak dan Hijauan Makanan Ternak (BPT-HMT) Provinsi Papua Barat di Distrik Masni Kabupaten Manokwari.

\section{Rancangan Penelitian}

Penelitian menggunakan rancangan acak lengkap pola faktorial (RAL $3 \times 4 \times 4)$. Faktor pertama adalah perlakuan kompos $(\mathrm{K})$ dengan 3 taraf, masing-masing K0 (tanpa kompos/kontrol), K1 (5 ton/ha kompos) dan K2 (10 ton/ha kompos). Faktor kedua adalah urea dengan 4 taraf, masing-masing N0 (tanpa urea), N1 $(150 \mathrm{~kg} / \mathrm{ha}$ urea $), \mathrm{N} 2(300 \mathrm{~kg} / \mathrm{ha}$ urea), N3 (450 kg/ha urea). Secara 
keseluruhan terdapat 12 kombinasi perlakuan dengan 4 ulangan.

\section{Prosedur Penelitian}

\section{a. Persiapan penelitian}

Tanah diayak, dibersihkan dari kotoran seperti gulma, akar, dan lainlain, kemudian dikering anginkan selama 1 minggu, ditimbang dan dimasukan polibag kurang lebih 20 kg. Polibag disusun sesuai hasil pengacakan. Sebelum penanaman Indigofera dalam polibag, terlebih dahulu tanah dan kompos dipersiapkan dicampur rata dan dimasukkan dalam polibag dan diberikan air secukupnya dan dibiarkan selama 1 minggu sebelum penanaman tanaman indigofera. Indigofera ditanam satu tanaman dalam setiap polibag. Contoh tanah dan kompos masing-masing diambil $1 \mathrm{~kg}$ untuk keperluan analisis sifat fisik dan kimia tanah.

\section{b. Pelaksanaan penelitian}

1. Penanaman

Penanaman dilakukan pada saat bibit sudah siap dipindah pada umur berumur 2 (dua) bulan. Bibit yang ditanam sehat dan berukuran seragam.
2. Pemupukan

Kompos atau tanah sebagai media tumbuh dimasukkan dalam polibag 1 minggu sebelum tanaman Indigofera dipindahkan. Pemupukan urea pertama diberikan setelah 7 hari penanaman dalam polibag dan sisanya diberikan lagi 30 hari setelah penanaman. Pupuk urea diberikan dengan cara disebar di sekitar tanaman dengan jarak 2 cm dari batang tanaman, dengan membuat alur lingkaran. Kompos diberikan dengan perlakuan K0 (100\% tanah atau $20 \mathrm{~kg}$ tanah), K1 (20 kg tanah + $50 \mathrm{~g}$ kompos), K2 (20 kg tanah + $100 \mathrm{~g}$ kompos). Urea diberikan sesuai perlakuan N0 (20 kg tanah tanpa urea), N1 (20 kg tanah $+3,260 \mathrm{~g}$ urea), N2 $(20 \mathrm{~kg}$ tanah $+6,521 \mathrm{~g}$ urea $), \mathrm{N} 3$ $(20 \mathrm{~kg}$ tanah $+9,782 \mathrm{~g}$ urea $)$.

3. Pemeliharaan tanaman

Penyiraman dilakukan setiap hari pada pagi atau sore hari, apabila media tanam masih lembab maka tidak dilakukan penyiraman. Penyulaman dilakukan pada umur 1 minggu setelah tanam terhadap 
tanaman yang mati dengan tanaman baru dari persemaian yang seumur. Penyiangan dilakukan sesuai dengan keadaan, apabila rumput tumbuh banyak dan mengganggu tanaman utama.

4. Persiapan sampel

Hasil panen/pemotongan hijauan ditimbang untuk mendapatkan berat segar hijauan, dicacah kemudian diambil sampel 500 g ditimbang menggunakan timbangan kapasitas 500 g dan kepekaan 0,01 g.

Sampel dimasukkan ke dalam amplop koran yang telah diketahui beratnya. Selanjutnya sampel dikeringkan dalam oven pada suhu $60^{\circ} \mathrm{C}$ selama 3 hari atau sampai beratnya konstan. Sampel hijauan digiling, kemudian disaring menggunakan saringan berukuran $1 \mathrm{~mm}$ untuk analisis proksimat dan penetapan bahan kering hijauan Indigofera.

Sampel dianalisa kandungan Protein Kasar (PK), Serat Kasar (SK), Lemak Kasar (LK) dan Bahan Ekstrak Tanpa Nitrogen
(BETN) pada Balai Pengujian Mutu Pakan Bekasi, Jawa Barat.

\section{Variabel Pengamatan}

Variabel yang diukur pada penelitian ini sebagai berikut:

1. Produksi hijauan segar (g/tanaman), diukur saat panen dengan cara menimbang berat tajuk tanaman setelah dipanen.

2. Produksi bahan kering (g/tanaman). Bahan kering merupakan hasil penetapan bahan segar hijauan yang dikeringkan dalam oven pada suhu $60^{\circ} \mathrm{C}$ dan dilanjutkan pada suhu $105^{\circ} \mathrm{C}$.

3. Rasio daun dan batang, dilakukan dengan menghitung perbandingan berat total daun dan berat total batang dari seluruh bagian tanaman di atas permukaan tanah saat panen.

4. Komposisi kimia (\%). Komposisi kimia hasil analisis proksimat sampel hijauan meliputi protein kasar (PK), serat kasar (SK), lemak kasar (LK), bahan ekstrak tanpa nitrogen (BETN) dan abu (AOAC, 2005). 
Analisis Data

Data dianalisis dengan menggunakan Sidik ragam (MANOVA). Bila memberikan pengaruh nyata dilanjutkan dengan uji Duncan (Steel dan Torrie, 1989).

\section{HASIL DAN PEMBAHASAN}

\section{Keadaan Umum Tanah dan Iklim}

Tanah yang digunakan dalam penelitian berasal dari BPT HMT Provinsi Papua Barat sebagaimana dilaporkan oleh Yafur (2017) memiliki sifat fisik tanah dengan struktur Angular Blocky, berwarna coklat tua dengan kadar air 28\%. Sedangkan sifat kimia tanah dengan nilai $\mathrm{pH} \mathrm{H}_{2} \mathrm{O}$ sebesar 5,9, $\mathrm{KCl}$ 5,0 (agak masam), nilai C Org (\%) 1,50 (rendah), Ntotal (\%) 0,24 (sedang), rasio $\mathrm{C} / \mathrm{N}$ sebesar 6 (rendah), $\mathrm{P}_{2} \mathrm{O}_{5}$ tersedia (ppm) 57,0, $\mathrm{P}_{2} \mathrm{O}_{5}$ potensil $(\mathrm{mg} / 100 \mathrm{~g}) 66$ kategori sangat tinggi dan nilai KTK (emol/kg) 9,55 (rendah) dan memiliki tekstur tanah lempung berliat. Data tersebut menunjukkan bahwa kondisi tanah tidak subur dengan kandungan bahan organik tanah minimal, sehingga perlu dilakukan penyediaan bahan organik dan unsur hara terutama Nitrogen.
Keadaan umum suhu selama penelitian periode bulan Mei-Juli 2018 bervariasi antara $28,3-35,0{ }^{\circ} \mathrm{C}$ dengan kelembaban 49-76\%. Kisaran suhu tersebut sesuai dengan lingkungan untuk pertumbuhan dan perkembangan tanaman I. zollingeriana yang berkisar antara 24-35 ${ }^{\circ} \mathrm{C}$ dan kelembaban 87 - $92 \%$ (Suharlina dan Abdullah, 2012). Kelembaban yang tinggi diduga karena pada akhir penelitian terjadi tingkat curah hujan yang tinggi. Suryowinoto (1988) mengemukakan bahwa terdapat dua faktor yang mempengaruhi pertumbuhan tanaman, yaitu faktor makro dan faktor mikro. Faktor makro meliputi cahaya matahari, suhu, kelembaban, awan, angin, serta pencemaran udara, sedangkan faktor mikro meliputi media tumbuh dan kandungan $\mathrm{O}_{2}$ dan $\mathrm{CO}_{2}$ di udara.

\section{Produksi Hijauan Segar}

Hasil analisis varians produksi hijauan segar tanaman I. zollingeriana menunjukkan bahwa perlakuan dosis pupuk urea berpengaruh sangat signifikan $(\mathrm{P}<0,01)$ terhadap produksi hijauan segar. Uji Duncan 
menunjukkan bahwa perlakuan dosis urea $450 \mathrm{~kg} / \mathrm{ha}(\mathrm{N} 3), 300 \mathrm{~kg} / \mathrm{ha}(\mathrm{N} 2)$ dan $150 \mathrm{~kg} / \mathrm{ha} \quad(\mathrm{N} 1)$ menghasilkan produksi hijauan segar lebih tinggi dibandingkan dengan perlakuan tanpa urea (N0), sedangkan antara perlakuan N1, N2 dan N3 tidak berbeda nyata. Peningkatan dosis pupuk urea dari 300 $\mathrm{kg} / \mathrm{ha}(\mathrm{N} 2)$ menjadi $450 \mathrm{kh} / \mathrm{ha}(\mathrm{N} 3)$ memberikan respon yang cenderung menurunkan produksi hijauan segar (Tabel 2). Kondisi ini mengindikasikan bahwa penambahan perlakuan dosis pupuk urea $300 \mathrm{~kg} / \mathrm{ha}$ adalah dosis pupuk yang sesuai dan menghasilkan produksi bahan segar hijauan tertinggi. Produksi hijauan dapat tercapai seoptimal mungkin jika macam dan jumlah hara yang ditambahkan dalam jumlah yang cukup dan seimbang dengan kebutuhan tanaman (Hakim, et al., 1986). Menurut Sirait, et al. (2009), I. zollingeriana dapat berproduksi secara optimum pada umur delapan bulan dengan rata-rata produksi biomasa segar per pohon sekitar 2,595 $\mathrm{kg} /$ panen. Diperkirakan jika tanaman $I$. Zollingerina dipanen pada umur 8 bulan akan menghasilkan rata-rata hijauan segar pada perlakuan N0 $(0,33$ $\mathrm{kg} /$ polibag) lebih rendah dari perlakuan $\mathrm{N} 3(0,56 \mathrm{~kg} /$ polibag $), \mathrm{N} 1$ $(0,57 \mathrm{~kg} /$ polibag $)$ dan $\mathrm{N} 2(0,62 \mathrm{~kg} /$ polibag).

Tabel 2. Rata-rata Produksi Hijauan segar I. Zollingerina (g/polibag) yang diberi Perlakuan Kompos dan Urea

\begin{tabular}{llllll}
\hline Pupuk & \multicolumn{5}{c}{ Pupuk Urea } \\
\cline { 2 - 5 } Kompos & N0 & N1 & N2 & N3 & \\
\hline K0 & 89,25 & 152,25 & 157,00 & 145,75 & 136,06 \\
K1 & 82,50 & 121,75 & 143,50 & 138,75 & 121,63 \\
K2 & 73,25 & 150,75 & 167,75 & 135,00 & 131,69 \\
\hline Rata -rata & $81,67^{\mathrm{b}}$ & $141,58^{\text {a }}$ & $156,08^{\text {a }}$ & $139,83^{\text {a }}$ & \\
\hline
\end{tabular}

Keterangan : Angka-angka yang tidak diikuti superskrip huruf menurut baris (pupuk urea) dan menurut kolom (pupuk kompos) serta menurut baris dan kolom (kombinasi kompos dan urea) tidak berbeda nyata $(\mathrm{P}>0,05)$. 


\section{Produksi Bahan Kering}

Rata-rata produksi bahan kering hijauan I. zollingeriana tertinggi diperoleh pada kombinasi perlakuan K2N2, K0N2, dan K0N1 berturut-turut $38,58,37,05$, dan 36,00, sedangkan berat kering terendah pada kombinasi perlakuan K2N0 yaitu sebesar 16,88 g (Tabel 3). Dwijosepoetro (1981) berpendapat bahwa bahan kering tanaman sangat dipengaruhi oleh optimalnya pemberian pupuk urea dan proses fotosintesis. Berat kering yang terbentuk mencerminkan banyak pemberian pupuk urea dan fotosintat sebagai hasil karena bahan kering sangat bergantung pada dosis pemberian pupuk dan laju fotosintesis. Hal lain yang mempengaruhi adalah persentase dari berat kering daun yang lebih banyak pada hijauan leguminosa dapat mempengaruhi kandungan karbohidrat dan protein semakin tinggi yang mengindikasikan kualitas hijauan semakin baik.

Tabel 3. Rata-rata Produksi Bahan Kering I. zollingerina (g) yang diberi Perlakuan Kompos dan Urea

\begin{tabular}{cc}
\hline Perlakuan & Produksi Bahan kering $(\mathrm{g})$ \\
\hline K0N0 & $20,90^{\mathrm{g}}$ \\
K0N1 & $36,00^{\mathrm{b}}$ \\
K0N2 & $37,05^{\mathrm{b}}$ \\
K0N3 & $34,17^{\mathrm{c}}$ \\
K1N0 & $19,30^{\mathrm{h}}$ \\
K1N1 & $28,37^{\mathrm{f}}$ \\
K1N2 & $33,27^{\mathrm{cd}}$ \\
K1N3 & $32,45^{\mathrm{d}}$ \\
K2N0 & $16,88^{\mathrm{i}}$ \\
K2N1 & $33,28^{\mathrm{cd}}$ \\
K2N2 & $38,58^{\mathrm{a}}$ \\
K2N3 & $30,92^{\mathrm{e}}$
\end{tabular}

Keterangan: Angka-angka yang diikuti superskrip yang berbeda menunjukkan berbeda sangat nyata $(\mathrm{P}<0,01)$

Tata (1995) menyatakan tidak selalu meningkatkan bahwa pemupukan yang berlebihan pertumbuhan dan produksi tanaman. 
Hal ini didukung oleh Novizan (2004) yang menyatakan bahwa tanaman justru tampak seperti kekurangan hara setelah diberi pupuk kompos yang belum terurai sempurna, tanaman akan bersaing dengan mikroorganisme tanah memperebutkan unsur hara.

\section{Rasio Daun dan Batang}

Rata-rata rasio daun dan batang tanaman I. zollingeriana akibat perlakuan dosis pupuk kompos, pupuk urea, dan kombinasi pupuk kompos dan pupuk urea tertinggi pada kombinasi perlakuan K1N2, K2N3 dan K0N3 berturut-turut 4,35, 4,07, dan $3,59 \%$, sedangkan rasio daun dan batang terendah pada kombinasi perlakuan K0N1, K2N0, dan K1N1 masing-masing 3,07, 3,06 dan 2,98\%. Rasio daun-batang merupakan indikator yang baik untuk menilai kualitas hijauan. Helai daun mempunyai kandungan protein yang lebih tinggi dibandingkan dengan bagian batang tanaman (Whitehead, 2000). Hal ini juga berarti bahwa kandungan protein pada batang cenderung lebih rendah dibandingkan dengan protein kasar fraksi daun. Ratarata rasio daun dan batang tanaman $I$. zollingeriana yang diberi perlakuan dosis pupuk kompos dan pupuk urea disajikan pada Tabel 4.

Tabel 4. Rata-rata Rasio Daun dan Batang I. zollingerina (\%) yang diberi Perlakuan Kompos dan Urea

\begin{tabular}{llllll}
\hline \multirow{2}{*}{ Kompos } & \multicolumn{5}{c}{ Urea } \\
\cline { 2 - 5 } & $\mathrm{N} 0$ & $\mathrm{~N} 1$ & $\mathrm{~N} 2$ & $\mathrm{~N} 3$ & \\
\hline K0 & 3,77 & 3,07 & 3,38 & 3,59 & 3,45 \\
K1 & 3,12 & 2,98 & 4,35 & 3,57 & 3,50 \\
K2 & 3,06 & 3,36 & 3,75 & 4,07 & 3,56 \\
\hline Rata -rata & 3,31 & 3,13 & 3,83 & 3,75 & \\
\hline
\end{tabular}

Keteragan: Angka-angka yang tidak diikuti superskrip huruf menurut baris (pupuk urea) dan menurut kolom (pupuk kompos) serta menurut baris dan kolom (kombinasi kompos dan urea) tidak berbeda nyata $(\mathrm{P}>0,05)$

Hasil analisis varian tidak berpengaruh signifikan $(\mathrm{P}>0,05)$. menunjukkan bahwa perlakuan pupuk Analisis varians dapat dilihat pada kompos, pupuk urea dan kombinasinya Tabel 4. Namun demikian dapat dilihat 
angka rata-rata rasio daun dan batang akibat perlakuan dosis pupuk kompos dari yang tertinggi ke rendah berturutturut K2 (10 ton/ha kompos) 3,56 \%, K1 (5 ton/ha kompos) 3,5\%, dan K0 (tanpa kompos) 3,45\%. Walaupun hasil uji Duncan bahwa pemberian pupuk tidak menunjukkan pengaruh terhadap pertumbuhan tetapi hasil penelitian ini menunjukkan kecenderungan peningkatan rasio daun dan batang pada dosis pemupukan kompos meningkatan rasio daun dan batang tanaman I. zollingeriana. Hal ini diduga disebabkan oleh ketersediaan nitrogen dalam tanah yang masih cukup dan sifat pupuk kompos yang lambat tersedia bagi tanaman. Menurut Kastono (2005) bahwa pengaruh tidak nyata dari perlakuan nitrogen dapat terjadi karena ketersediaan unsur nitrogen dalam tanah masih cukup dan kemungkinan kehadiran unsur nitrogen menjadi bentuk tersedia bagi tanaman belum dapat diserap oleh akar tanaman.

\section{Komposisi Kimia}

Komposisi kimia I. zollingeriana yang diberi perlakuan dosis kompos dan urea disajikan pada Tabel 5.

Tabel 5. Komposisi Kimia (\%) I. zollingeriana yang diberi perlakukan Kompos dan Urea

\begin{tabular}{lcccccc}
\hline & $\begin{array}{c}\text { Bahan } \\
\text { Kering }\end{array}$ & $\begin{array}{c}\text { Bahan } \\
\text { Organik }\end{array}$ & $\begin{array}{c}\text { Protein } \\
\text { Kasar }\end{array}$ & $\begin{array}{c}\text { Lemak } \\
\text { kasar }\end{array}$ & $\begin{array}{c}\text { Serat } \\
\text { Kasar }\end{array}$ & BETN \\
\hline K0N0 & 93,63 & 90,23 & 23,79 & 1,91 & 31,93 & 32,56 \\
K0N1 & 94,64 & 91,34 & 22,71 & 1,81 & 38,43 & 28,39 \\
K0N2 & 94,35 & 90,29 & 24,58 & 2,07 & 32,28 & 31,36 \\
K0N3 & 93,8 & 89,55 & 27,27 & 1,90 & 32,1 & 32,73 \\
K1N0 & 93,41 & 88,45 & 17,73 & 1,70 & 34,08 & 34,94 \\
K1N1 & 93,28 & 90,50 & 21,46 & 2,92 & 34,37 & 31,75 \\
K1N2 & 93,04 & 90,14 & 25,64 & 2,29 & 30,48 & 31,73 \\
K1N3 & 93,51 & 89,78 & 24,57 & 2,61 & 27,88 & 34,71 \\
K2N0 & 92,23 & 89,65 & 17,77 & 1,69 & 35,01 & 35,17 \\
K2N1 & 92,44 & 90,12 & 21,27 & 2,32 & 33,48 & 33,06 \\
K2N2 & 92,00 & 88,75 & 25,07 & 5,76 & 28,38 & 29,56 \\
K2N3 & 91,64 & 88,47 & 26,16 & 2,20 & 28,84 & 31,25 \\
\hline
\end{tabular}


Kandungan Protein Kasar (PK) pada penelitian ini berkisar antara $17,77-27,27 \%$ tidak berbeda jauh dengan penelitian yang dilakukan Herdiawan (2014) yang menyatakan kandungan PK berkisar antara 22-28\%. dan 23,10\% (Ali, et al., 2014). Pada penelitian ini terjadi kecenderungan peningkatan kandungan PK pada dosis pemupukan N3 (450 kg/ha urea). Hal ini diduga karena tingginya kandungan nitrogen dalam pupuk sehingga meningkatkan kandungan PK. Peningkatan kandungan PK diduga karena terdapatnya sumber nitrogen yang tinggi dari tanaman $I$. zollingerina. Baldwin

meyatakan bahwa penambahan urea juga dapat meningkatkan total $\mathrm{N}$ dalam bahan pakan sehingga turut menunjang kenaikan protein kasar. Proses amoniasi oleh urea akan menyebabkan fiksasi nitrogen dan nitrogen yang terfiksasi ini yang nantinya akan dihitung sebagai protein kasar.

Rata-rata kisaran lemak kasar pada penelitian ini berkirar antara 1,7 - 5,76\% dengan lemak kasar tertinggi pada perlakuan K2N2 sebesar 5,76\%. Menurut Abdullah, et al. (2010) bahwa rata-rata lemak kasar tanaman Indigofera berkisar 3,62 \%. Kandungan lemak kasar pada perlakuan K2N2 penelitian ini lebih tinggi, namun lebih rendah dibandingkan dengan hasil yang dilaporkan oleh Sirait, et al. (2009) menyatakan kandungan lemak kasar I. zollingeriana sebesar $6,15 \%$. Santoso, et al. (2012) yang menyatakan bahwa pada ternak ruminansia, kandungan lemak dalam pakan disarankan tidak melebihi 5\% karena kandungan lemak yang tinggi akan mempengaruhi aktivitas mikroba rumen yaitu menurunkan populasi mikroba pencerna serat.

Serat kasar pada penelitian ini antara 27,88\%- 38,43\%. Menurut Herdiawan rata-rata serat kasar tanaman I. zollingerina adalah 18,18 $\%$. Tingginya serat kasar pada perlakuan diduga karena imbangan antara daun dan batang yang lebih banyak dipengaruhi batang tanaman $I$. zollingerina. Menurut Chen, et al. (2009), kualitas dan kuantitas hijauan selalu mengalami perubahan bergantung pada pemanenan. Daun lebih mudah tercerna dan memiliki 
kandungan serat kasar yang lebih rendah dibandingkan batang, dan memiliki kandungan protein kasar 2-3 kali lebih tinggi dibandingkan batang (Putnam, et al., 2007).

Nilai BETN tertinggi pada penelitian ini adalah sebesar $35,17 \%$, lebih rendah dibandingkan dengan kadar BETN silase Indigofera pada perlakuan tanpa penambahan pelepah kelapa sawit adalah sebesar $57,00 \%$, tetapi lebih tinggi jika dibandingkan dengan pemberian pelepah kelapa sawit $20 \%, 40 \%$ dan $60 \%$ berturutturut $56,72 \%, 54,70 \%$ dan $52,95 \%$. Kusumaningrum, et al. (2012) menyatakan bahwa BETN dapat dikatakan sebagai karbohidrat yang larut, berkebalikan dengan SK yang merupakan polisakarida yang tidak dapat larut. Tillman, et al. (1989) menambahkan bahwa BETN berisi zat-zat monosakarida, disakarida, trisakarida dan polisakarida terutama pati yang mudah larut dalam larutan asam dan basa dalam analisis serat kasar dan mempunyai daya cerna yang tinggi.

\section{KESIMPULAN}

Kombinasi perlakuan kompos dan urea berpengaruh sangat signifikan terhadap produksi bahan kering I.zollingerina. Kombinasi perlakuan 10 ton kompos/ha dengan $300 \mathrm{~kg}$ urea/ha (K2N2) menghasilkan produksi bahan kering Indigofera zollingeriana tertinggi.

\section{DAFTAR PUSTAKA}

Abdullah, L. 2010. Herbage production and quality of shrub Indigofera treated by different concentration of foliar fertilizer. Media Peternakan 33(3): 169175.

Ali, A., L. Abdullah, P.D.M.H. Karti, M.A. Chozin and Astuti. 2014. Production and Nutritive Value of Indigofera zollingeriana and Leucaena leucocephala in Peatland. Bogor Agricultural University.

AOAC. 2015. Official Method of Analysis of the Association of Official Analitycal Chemists. Ed ke-16 . Maryland (US): AOAC International.William Harwitz (ed).

Baldwin, B. G., M.J. Sanderson, J.M. Porter, M.F. Wojciechowski, C.S. Campbell, and M.J. Donoghue. 1995. The ITS region of nuclear ribosomal DNA: a valuable source of evidence on 
angiosperm phylogeny. Annals of the Missouri botanical garden 82: 247-277.

Balitbangda Pertanian. 2014. Indigofera spicata. Tanaman Pakan ternak Toleran Kekeringan dengan kandungan protein tinggi. Edisi tanggal 21 April 2014.

Chen, X., K.M. Engle, D.H. Wang, and J.Q. Yu. 2009. Palladium (II)-catalyzed $\mathrm{C} \mathrm{H}$ activation/C $\square$ $\mathrm{C}$ cross-coupling reactions: versatility and practicality. Angewandte Chemie International Edition 48(28): 5094-5115.

Dwijosapoetro, D. 1981. Pengantar fisiologi Tanaman.PT. Gramedia Pustaka Utama. Jakarta.

Hakim, N, M.Y. Nyakpa, A.M. Lubis, S.G. Nugroho, M.R. Saul, M.A. Diha, G. B. Hong, dan H.H. Bailey. 1986. Dasar-dasar Ilmu Tanah. Universitas Lampung. Lampung.

Handayanto, E. 1999. Komponen biologi tanah sebagai bioindikator kesehatan dan produktivitas tanah. Universitas Brawijaya. Malang.

Hartatik, W., H. Husnain, dan L.R. Widowati. 2015. Peranan pupuk organik dalam peningkatan produktivitas tanah dan tanaman. Jurnal Sumberdaya Lahan, 9(2): 107-120.
Herdiawan, I. 2014. Pertumbuhan tanaman pakan ternak leguminosa pohon Indigofera zollingeriana pada berbagai taraf perlakuan cekaman kekeringan. Jurnal Ilmu Ternak dan Veteriner. 18, 258-264.

Jaya, R.R. 2016. A simple and new optimization algorithm for solving constrained and unconstrained optimization problems. International Journal of Industrial Engineering Computations. 7(1):19-34.

Kastono, D. 2005. Tanggapan pertumbuhan dan hasil kedelai hitam terhadap penggunaan pupuk organik dan biopestisida gulma siam (Chromolaena odorata). Ilmu pertanian, 12(2): 103-116.

Khamsekhiew, B., J.B. Liang, C.C. Wong, and Z.A. Jelan. 2001. Ruminal and Instetinal Digggestibility of Some Tropical legume forages. AsianAustralasian Journal of Animal Sciences 14:321-32.

Koten, B.B., R. Wea, R.D. Soetrisno, N. Ngadiyono, dan B. Soewignyo. 2014. Konsumsi nutrien ternak kambing yang mendapatkan hijauan hasil tumpang sari arbila (Phaseolus lunatus) dengan sorghum sebagai tanaman sela pada jarak tanam arbila dan jumlah baris sorgum yang berbeda. Jurnal Ilmu Ternak 1 (8): $38-45$. 
Kusumaningrum, M., C.I. Sutrisno, dan B.W.H.E Prasetiyono. 2012. Kualitas Kimia Ransum Sapi Potong Berbasis Limbah Pertanian dan Hasil Samping Pertanian yang Difermentasi dengan Aspergillus niger. Animal Agriculture Journal. 1: $109-119$.

Santoso, S.E., L. Soesanto, dan T.A.D. Haryanto. 2012. Penekanan hayati penyakit moler pada bawang merah dengan Trichoderma harzianum, Trichoderma koningii dan Pseudomonas fluorescens P60. Jurnal Hama dan Penyakit Tumbuhan Tropika. 7(1):53-61.

Sirait, J., K. Simanihuruk, dan R. Hutasoit. 2009. The potency of Indigofera sp. as goat feed: production, nutritive value and palatability. In: Proceeding of International Seminar on Forage Based Feed Resources. Bandung, 3-7 Agustus 2009. Taipei (Taiwan): Food and Fertilizer Technology Centre (FFTC) ASPAC, Livestock Research Centre-COA, ROC and IRIAP. p.4-7.

Steel, R.G.D dan J.H. Torrie. 1989. Prinsip dan Prosedur Statistika Suatu Pendekatan Biometrik (terjemahan: Bambang Sumantri) Edisi-2. PT. Gramedia. Jakarta.

Stevenson, F.T. 1982. Humus Chemistry. John Wiley and Sons, New York.
Suharlina dan L. Abdullah. 2012. Peningkatan produktivitas Indigofera sp. Sebagai pakan hijauan berkualitas tinggi melalui aplikasi pupuk organik cair : 1. Produksi hijauan dan dampaknya terhadap kondisi tanah. Pastura. 1(2): 39-43.

Tarigan, A. L., S.P. Abdullah, dan I.G. Permana. 2010. Produksi dan komposisi nutrisi serta kecernakan in vitro Indigofera sp. pada interval dan tinggi pemotongan berbeda. Jurnal Ilmu Ternak dan Veteriner. 15(3): 188-195.

Tillman, N., A. Ulman, \& T.L. Penner. 1989. Formation of multilayers by selfassembly. Langmuir. 5(1): 101111.

Whitehead, D. C. 2000. Nutrient elements in grassland: soil-plantanimal relationships. Wallingford: CABI Publishing.

Yafur, F. 2017. Laporan Hasil Pengujian Sifat Kimia Tanah. Seameo Biotrop Service Laboratory. Bogor. 